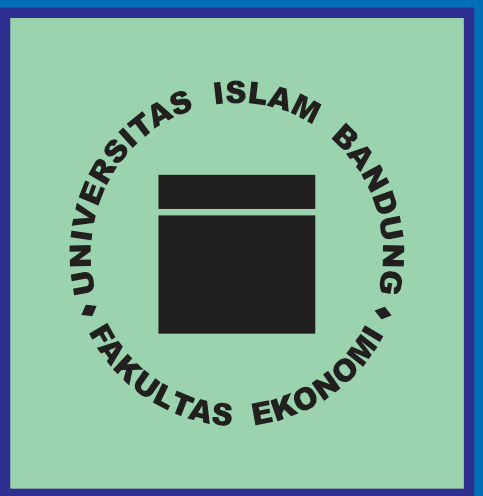

Vol.21 No.2

September 2020

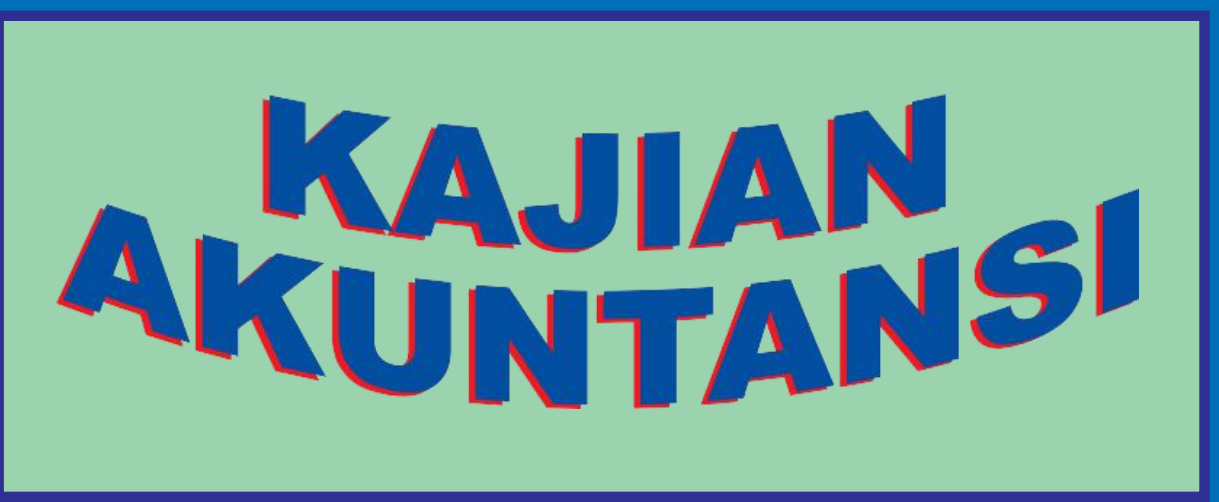

ISSN : 1693 - 0614 e-ISSN : 2581 - 074X
Deliana, Abdul Rahman

Ilham Hidayah Napitupulu, Anggiat Situngkir,

Chairunnisa Arfanni

Edi Sukarmanto, Magnaz Lestira Oktaroza, Karina Nur Astari

Eka Nurmala Sari, Muhyarsyah, Nunung Sri Wahyuni

Nurhayati, Muhammad Kevin Aprilio

Uli Wildan Nuryanto, Masyhudzulhak

Djamil MZ, Achmad Hidayat Sutawidjaya, Ahmad Badawi Saluy.

Riyang Mardini

Annisa Nadiyah

Rahmani

Diamonalisa Sofianty, Lena Herlina.
Efektivitas Audit Internal Pada Perguruan Tinggi Negeri Di Provinsi Sumatera Utara.

Pengaruh Transfer Pricing Dan Profitabilitas Terhadap Tax Avoidance.

Related Party Transaction Memperkuat Pengaruh Political Connection Terhadap Audit Delay?

Pengaruh Sistem Pengendalian Intern Pemerintah Dan Ketersediaan Anggaran Terhadap Efektivitas Penerapan Sistem Informasi Keuangan Daerah Pada Pemerintah Provinsi Dan Kabupaten/Kota Se-Sumatera Utara.

Pengaruh Rasio Solvabilitas Terhadap Kondisi Financial Distress

Implikasi Keunggulan Bersaing Terhadap Kinerja Organisasi Pada Sektor Industri Manufaktur Kimia di Provinsi Banten

Pengaruh Kinerja ICSR Terhadap Readability ICSR Menggunakan Gunning Fog Dan Flesch-Kincaid Indeks Dengan Size, Kinerja Keuangan, Leverage Dan Growth Sebagai Variabel Kontrol.

Dampak Covid-19 Terhadap Harga Saham Dan Kinerja Keuangan Perusahaan

Pengaruh Pengungkapan Corporate Social Responsibility Dan Mekanisme Good Corporate Governance Terhadap Tax Avoidance

Diterbitkan oleh :

ISSN

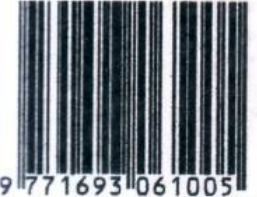

( P 2 U )

Pusat Penerbitan Universitas 


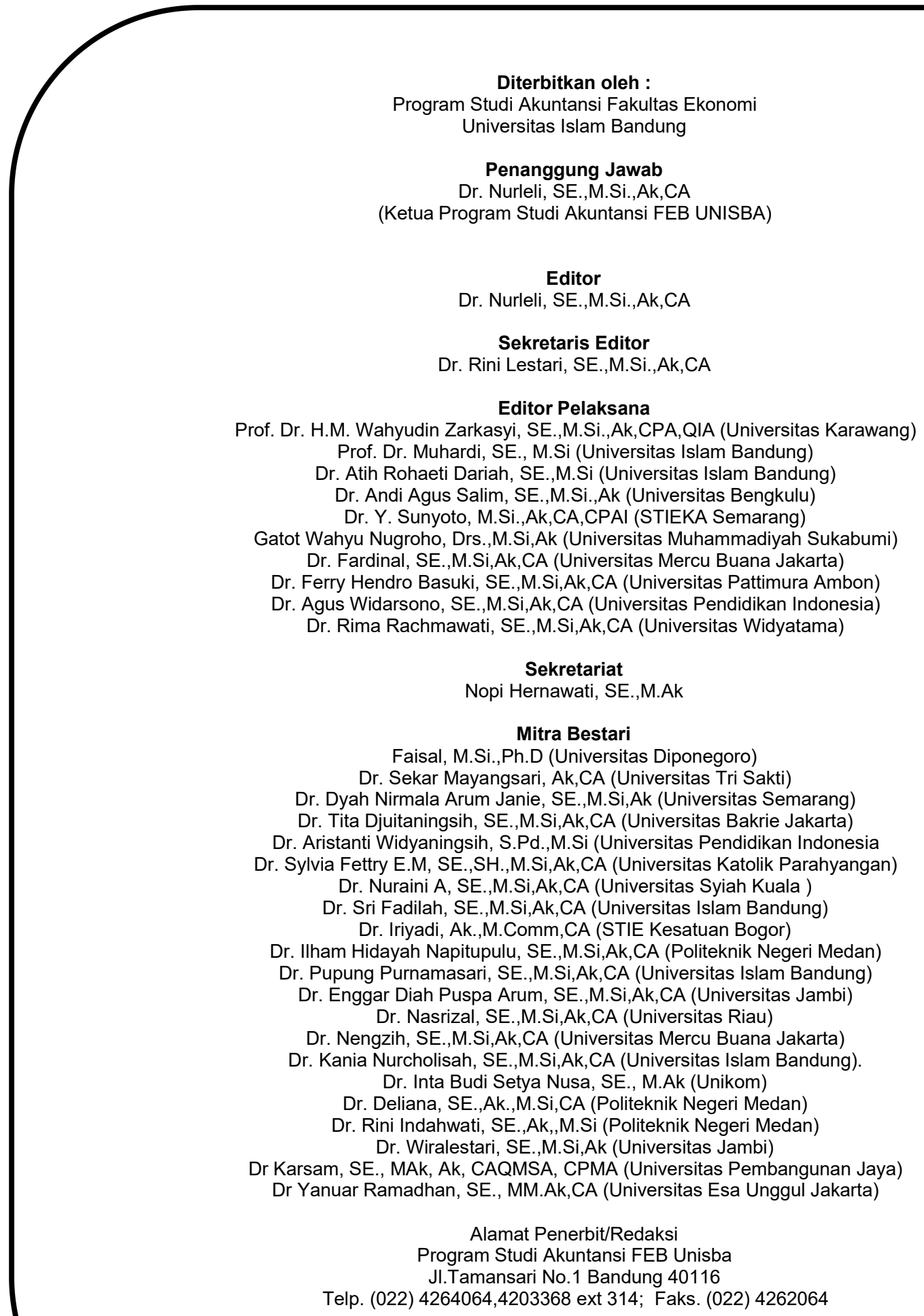

Terbit dua kali dalam setahun : Maret dan September Terbit pertama kali Maret 2003

Redaksi menerima naskah berupa artikel penelitian maupun artikel hasil pengkajian. Pendapat yang dimuat dalam jurnal ini sepenuhnya pendapat pribadi penulis ,

tidak mencerminkan pendapat redaksi,

dan telah disajikan menurut sistematika yang ditetapkan pada halaman akhir jurnal ini . 


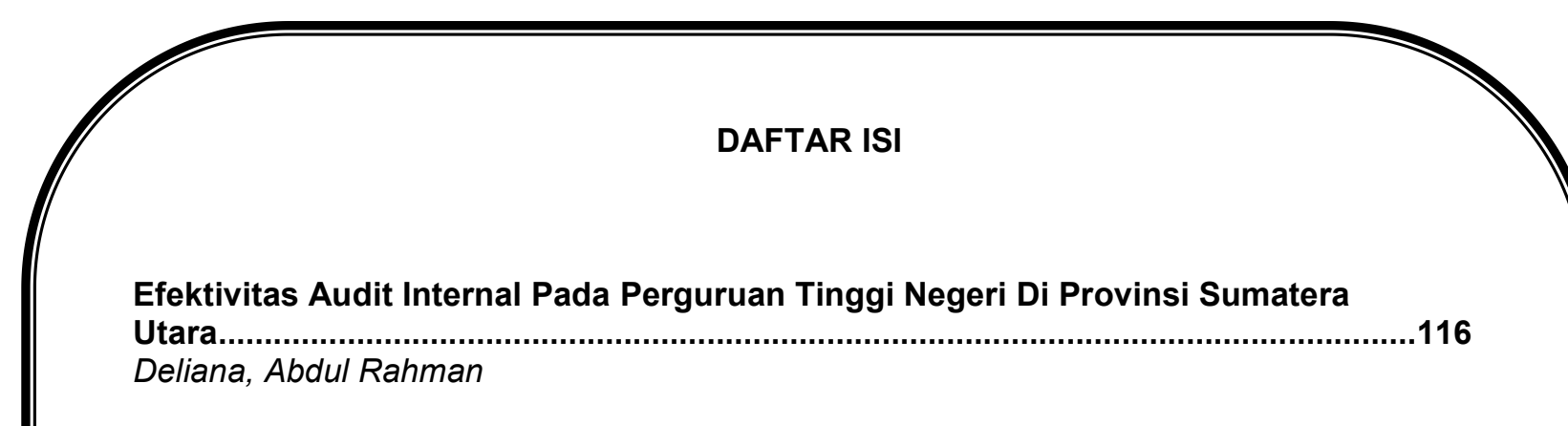

Pengaruh Transfer Pricing Dan Profitabilitas Terhadap Tax Avoidance .126

Ilham Hidayah Napitupulu, Anggiat Situngkir, Chairunnisa Arfanni

Related Party Transaction Memperkuat Pengaruh Political Connection

Terhadap Audit Delay?

Edi Sukarmanto, Magnaz Lestira Oktaroza, Karina Nur Astari

Pengaruh Sistem Pengendalian Intern Pemerintah Dan Ketersediaan Anggaran Terhadap Efektivitas Penerapan Sistem Informasi Keuangan Daerah Pada Pemerintah Provinsi Dan Kabupaten/Kota Se-Sumatera Utara.

Eka Nurmala Sari, Muhyarsyah, Nunung Sri Wahyuni

Pengaruh Rasio Solvabilitas Terhadap Kondisi Financial Distress Nurhayati, Muhammad Kevin Aprilio

Implikasi Keunggulan Bersaing Terhadap Kinerja Organisasi Pada Sektor Industri Manufaktur Kimia di Provinsi Banten.

Uli Wildan Nuryanto, Masyhudzulhak Djamil MZ, Achmad Hidayat Sutawidjaya,

Ahmad Badawi Saluy

Pengaruh Kinerja ICSR Terhadap Readability ICSR Menggunakan Gunning Fog Dan Flesch-Kincaid Indeks Dengan Size, Kinerja Keuangan, Leverage Dan Growth Sebagai Variabel Kontrol

Riyang Mardini

Dampak Covid-19 Terhadap Harga Saham Dan Kinerja Keuangan Perusahaan. Annisa Nadiyah Rahmani.

Pengaruh Pengungkapan Corporate Social Responsibility Dan Mekanisme Good Corporate Governance Terhadap Tax Avoidance.

Diamonalisa Sofianty, Lena Herlina I 
PENGARUH SISTEM PENGENDALIAN INTERN PEMERINTAH DAN

\title{
KETERSEDIAAN ANGGARAN TERHADAP EFEKTIVITAS PENERAPAN \\ SISTEM INFORMASI KEUANGAN DAERAH PADA PEMERINTAH \\ PROVINSI DAN KABUPATEN/KOTA SE-SUMATERA UTARA
}

\author{
Eka Nurmala Sari \\ University Of Muhammadiyah \\ Sumatera Utara \\ ekanurmala@umsu.ac.id
}

\author{
Muhyarsyah \\ University Of Muhammadiyah \\ Sumatera Utara \\ otanjung@yahoo.co.id
}

\author{
Nunung Sri Wahyuni \\ University Of Muhammadiyah \\ Sumatera Utara \\ nunungsw.bkdsu@gmail.com
}

\begin{abstract}
This study aims to determine, test and analyze the effect of SPIP (Government Internal Control System) and budget availability on the effectiveness of implementing regional financial information systems either partially or simultaneously. The research method used is quantitative data analysis. The objects of this research are all local governments in North Sumatra Province. The sampling used in this research is saturated sampling method. The data collection technique was carried out by distributing questionnaires. While the data analysis technique is using multiple linear regression analysis which is processed using SPSS statistical software. The results showed that the SPIP had no effect on the effectiveness of the implementation of the regional financial information system. Meanwhile, budget availability has an effect on the effectiveness of implementing the regional financial information system. And simultaneously SPIP and budget availability affect the effectiveness of the implementation of regional financial information systems.
\end{abstract}

Keywords: Government Internal Control System, Budget Availability, Effectiveness of the Implementation of Regional Financial Information Systems.

\begin{abstract}
Abstrak
Penelitian ini bertujuan untuk mengetahui, menguji dan menganalisis pengaruh SPIP (Sistem Pengendalian Intern Pemerintah) dan ketersediaan anggaran terhadap efektivitas penerapan sistem informasi keuangan daerah baik secara parsial maupun simultan. Metode penelitian yang digunakan adalah analisis data kuantitatif. Objek pada penelitian ini adalah seluruh Pemerintah Daerah pada Provinsi Sumatera Utara. Sampling yang digunakan pada penelitian ini adalah menggunakan metode sampling jenuh. Teknik pengumpulan data dilakukan melalui pendistribusian kuesioner. Sedangkan teknik analisis data adalah menggunakan analisis regresi linear berganda yang diproses menggunakan perangkat lunak statistik SPSS. Hasil penelitian menunjukkan bahwa SPIP
\end{abstract}


tidak berpengaruh terhadap efektivitas penerapan sistem informasi keuangan daerah. Sementara ketersediaan anggaran berpengaruh terhadap efektivitas penerapan sistem informasi keuangan daerah. Dan secara simultan SPIP dan ketersediaan anggaran berpengaruh terhadap efektifitas penerapan sistem informasi keuangan daerah.

\section{Kata kunci : Sistem Pengendalian Intern Pemerintah, Ketersediaan Anggaran, Efektivitas Penerapan Sistem Informasi Keuangan Daerah.}

\section{PENDAHULUAN}

Kebijakan pemerintah mengenai perubahan prinsip sentralisasi menjadi desentralisasi pada era otonomi daerah di Indonesia mengakibatkan perubahan yang cukup mendasar dalam mekanisme penyelenggaraan pemerintah, yang berakibat terhadap perkembangan pengelolaan administrasi publik. Dengan adanya pelaksanaan desentralisasi diharapkan setiap daerah semakin efisien dan efektif dalam mengatur proses pembangunannya karena daerah mendapat pelimpahan wewenang dan kebebasan yang luas untuk mengatur kebijakan-kebijakan penting demi kemajuan daerahnya (Syarifudin, 2014).

Salah satu perubahan mendasar dalam mekanisme penyelenggaraan konsep otonomi daerah adalah tentang pengelolaan keuangan daerah, dimana organisasi sektor publik umumnya bergantung pada alokasi anggaran pemerintah untuk pendanaan dalam melaksanakan pelayanan publik. Bentuk pertanggungjawaban pengelolaan keuangan dalam penyelenggaraan pemerintahan daerah diatur dalam Undang-Undang Nomor 32 Tahun 2004 tentang Pemerintahan Daerah dan Undang-Undang Nomor 17 Tahun 2003 tentang Keuangan Negara. Regulasi tersebut menimbulkan konsekuensi bagi Pemerintah Daerah agar dapat mengelola keuangan daerah dan menghasilkan laporan keuangan yang bersifat transparansi dan memiliki akuntabilitas. Akuntabilitas merupakan bentuk kewajiban mempertanggungjawabkan keberhasilan atau kegagalan pelaksanaan misi organisasi dalam mencapai tujuan dan sasaran yang telah ditetapkan sebelumnya, melalui suatu media pertanggungjawaban yang dilaksanakan secara periodik (Mardiasmo, 2006).

Beberapa fenomena yang ditemukan dalam laporan IHPS BPK menyatakan bahwa masih terdapat 131 Laporan Keuangan Pemerintah Daerah (LKPD) yang belum memperoleh opini Wajar Tanpa Pengecualian (WTP) dikarenakan terdapat akun-akun dalam laporan keuangan yang disajikan tidak sesuai dengan Standar Akuntansi Pemerintahan (SAP) dan/atau tidak didukung dengan bukti yang cukup. Proses penyusunan laporan keuangan daerah agar sesuai dengan peraturan perundang-undangan 
harus didukung oleh teknologi informasi yang memadai (Arfianti, 2011). Menurut (Hall, 2004) mengungkap bahwa, The quality of information generated by the accounting information sistem impacts management's ability to take actions and make decisions in connection with the organization's operations and to prepare reliable financial statements.

Kompleksitas permasalahan yang dihadapi oleh pemerintah daerah semakin bertambah dengan meningkatnya total jumlah anggaran yang dilaksanakan setiap tahunnya (Suarmika \& Suputra, 2016). Dari sisi akuntansi hal tersebut menunjukkan bahwa volume transaksi keuangan pemerintah menunjukkan kuantitas yang semakin besar dan kualitas yang semakin rumit dan kompleks. Peningkatan volume transaksi yang semakin besar dan semakin kompleks harus diikuti dengan pemanfaatan teknologi informasi dalam pengelolaan keuangan pemerintah (Efendi, Darwanis, \& Abdullah, 2017). Berdasarkan Pasal 96 ayat (2) Peraturan Pemerintah Nomor 58 Tahun 2005 tentang Pengelolaan Keuangan Daerah, Pemerintah Daerah diberikan kewenangan untuk menetapkan sistem akuntansi pemerintah daerah dengan peraturan kepala daerah mengacu pada peraturan daerah tentang pengelolaan keuangan daerah. Data dari Kementerian Keuangan, terdapat beragam jenis sistem informasi akuntansi yang digunakan oleh Pemerintah Daerah di Indonesia adalah sebagai berikut :

\section{Tabel 1}

\section{Daftar Sistem Informasi Keuangan Pemerintah Daerah}

\begin{tabular}{|c|l|l|c|c|}
\hline No & \multicolumn{1}{|c|}{ Nama Aplikasi } & Pembuat & Pengguna & \% \\
\hline 1 & $\begin{array}{l}\text { Sistem Informasi Manajemen } \\
\text { Daerah (SIMDA) }\end{array}$ & BPKP & 369 & $68 \%$ \\
\hline 2 & $\begin{array}{l}\text { Sistem Informasi Pengelolaan } \\
\text { Keuangan Daerah (SIPKD) }\end{array}$ & Kemendagri & 92 & $17 \%$ \\
\hline 3 & $\begin{array}{l}\text { Sistem Informasi Anggaran dan } \\
\text { Keuangan Daerah (SIMAKDA) }\end{array}$ & PT MSM & 27 & $5 \%$ \\
\hline 4 & E-Finance & PT STI & 11 & $2 \%$ \\
\hline 5 & SIMRAL & BPPT & 5 & $1 \%$ \\
\hline 6 & Sistem Lainnya Total & - & 38 & $7 \%$ \\
\hline & & $\mathbf{5 4 2}$ & $\mathbf{1 0 0 \%}$ \\
\hline
\end{tabular}

Sumber : Kementerian Keuangan RI

Dalam rangka mengatasi keragaman sistem informasi akuntansi pemerintah daerah, Kementerian Keuangan telah menetapkan peraturan yang mewajibkan Pemerintah Daerah untuk menyampaikan data informasi keuangan daerah dalam format 
yang ditetapkan ke dalam Sistem Informasi Keuangan Daerah. Namun masih terdapat tantangan dalam peningkatan kualitas data, untuk memastikan keandalan data yang dikirimkan sesuai dengan kinerja dan posisi keuangan pemerintah daerah serta ketepatan waktu penyampaian data laporan keuangan pemerintah daerah secara berkala (Kementerian Keuangan RI, 2018).

Menurut (Elvira Zeyn, 2012) content pelaporan, keakurasian angka-angka yang tertera di laporan keuangan dihasilkan oleh sistem akuntansi yang memadai untuk akuntabilitas pelaporan itu sendiri. Oleh karena itu, untuk menghasilkan laporan pertanggungjawaban yang berkualitas, tentunya memerlukan sarana dan prasarana yang memadai, disertai dengan pembelajaran terhadap sumber daya manusia yang dimiliki oleh pemerintah daerah agar dapat memahami dan melaksanakan sistem yang baru dalam pengelolaan dan pertanggungjawaban keuangan daerah (Ratifah \& Ridwan, 2012).

Dalam rangka membangun efektivitas penerapan sistem informasi akuntansi maka diperlukan sistem pengendalian internal (Sari, 2015). Mengingat perkembangan kualitas laporan keuangan yang masih terlihat lambat, maka peningkatan kompetensi SDM dan peran pengawas keuangan serta efektivitas pengendalian intern pemerintah menjadi krusial. Sistem pengendalian intern akan sangat efektif bila pengendalian tersebut menyatu dengan infrastruktur dan merupakan bagian penting bagi organisasi (Susanto, 2008). Dengan mengoptimalkan sistem pengendalian intern pemerintah (SPIP) diharapkan pengendalian intern semakin efektif sehingga dapat memediasi dalam mengatasi permasalahan rendahnya kualitas informasi keuangan (Syarifudin, 2014).

Terbitnya Peraturan Pemerintah No.60 tahun 2008 tentang Sistem Pengendalian Intern Pemerintah menngemukakan bahwa pengawas intern memiliki peran baru yang melakukan fungsi pengawasan internal terhadap akuntabilitas keuangan negara dan daerah, pembinaan penyelenggaraan SPIP, dan reviu laporan keuangan pemerintah pusat dan daerah (Syarifudin, 2014). Dengan demikian, tugas pengawas tidak hanya mengawasi pengelolaan keuangan tetapi melakukan sinergitas dengan pengelola keuangan baik di pemerintah pusat maupun di pemerintah daerah dalam rangka meningkatkan kualitas laporan keuangan. Keandalan informasi yang disajikan dalam laporan keuangan sangat ditentukan oleh baik atau tidaknya pengendalian intern akuntansi yang berlaku dalam pemerintahan (Mulyadi, 2008). Menurut (Simanjuntak, 2012) bahwa SPIP itu vital sekali, kalau ingin memperbaiki sistem pengelolaan keuangan Pemda, maka perbaiki dulu 
pondasinya, yaitu dengan SPIP, dengan memperbaiki SPIP maka sistem informasi dapat lebih berkualitas.

Faktor lainnya yang dianggap mempengaruhi efektivitas sistem informasi keuangan daerah adalah anggaran. Lingkup anggaran menjadi relevan dan penting di lingkungan pemerintah daerah. Hal ini terkait dengan dampak anggaran terhadap akuntabilitas pemerintah, sehubungan dengan fungsi pemerintah dalam memberikan pelayanan kepada masyarakat (Idris, 2013). Oleh sebab itu, dalam menghasilkan sistem informasi yang berkualitas juga tidak terlepas dari faktor ketersediaan anggaran. Faktor ketersediaan anggaran (financial) menjadi suatu hal yang penting dalam meningkatkan kinerja yang berkaitan dengan pelaksanaan tugas untuk mencapai tujuan dan meningkatkan profesionalisme hasil kerja (Idris, 2013). Rencana pembangunan tidak dapat dijalankan tanpa adanya kepastian ketersediaan anggaran yang mampu mengakomodir kebutuhan masyarakat, dunia usaha dan pemerintah (Ir. H. Dede Hermasah, 2008).

Ketersediaan anggaran yang disusun oleh Pemerintah Daerah sebahagian besar dialokasikan untuk belanja pegawai. Berdasarkan data Direktorat Jenderal Perimbangan Keuangan, rata-rata porsi belanja pegawai dalam APBD 2015, baik provinsi maupun kabupaten/kota mencapai 40\%. Hal ini mengakibatkan kualitas APBD di berbagai daerah di nilai masih rendah karena sebagian besar uang APBD masih dialokasikan untuk belanja pegawai negeri. Oleh karena itu Pemerintah pusat meminta pemerintah daerah (Pemda) untuk memperbaiki kualitas belanja dalam Anggaran Pendapatan dan Belanja Daerah (APBD) Mardiasmo (2017).

Berdasarkan uraian-uraian di atas, maka peneliti tertarik untuk melakukan penelitian lebih lanjut mengenai pengaruh sistem pengendalian intern pemerintah dan ketersediaan anggaran terhadap efektivitas penerapan sistem informasi keuangan daerah dengan subjek penelitian pada Pemerintah Provinsi dan Pemerintah Kabupaten/Kota yang ada di Sumatera Utara.

\section{LANDASAN TEORI}

\subsection{Efektivitas Penerapan Sistem Informasi Keuangan Daerah}

Pada sistem informasi akuntansi pemerintah, ada beberapa ciri penting atau persyaratan yang diperlukan, diantaranya sistem informasi akuntansi pemerintah harus 
dirancang sesuai dengan konstitusi dan peraturan perundang-undangan yang berlaku pada sebuah negara (Sari, 2015). Sistem akuntansi pemerintah harus dapat menyediakan informasi yang dapat dipertanggungjawabkan dan diaudit. Sistem akuntansi pemerintah harus mampu menyediakan informasi keuangan yang diperlukan untuk penyusunan rencana/program dan evaluasi pelaksanaan secara fisik dan keuangan (Iman Bastari (Anggota Komite Kerja Standar Akuntansi Pemerintahan, 2004).

Dalam Undang-undang Nomor 33 Tahun 2004 tentang Perimbangan Keuangan antara Pusat dan Pemerintah Daerah mengamanatkan adanya dukungan Sistem Informasi Keuangan Daerah untuk menunjang perumusan kebijakan fiskal secara nasional serta meningkatkan tranparansi dan akuntabilitas dalam pelaksanaan desentralisasi. Sistem informasi akuntansi pada pemerintah daerah dikenal dengan nama Sistem Informasi Keuangan Daerah (SIKD). SIKD yang dilaksanakan pada pemerintah daerah mengacu kepada Peraturan Pemerintah (PP) Republik Indonesia Nomor 56 tahun 2005 (P. R. Indonesia, 2005) tentang Sistem Informasi Keuangan Daerah (SIKD) yang menyatakan bahwa SIKD adalah suatu sistem yang mendokumentasikan, mengadministrasikan, serta mengolah data pengelolaan keuangan daerah dan data terkait lainnya menjadi informasi yang disajikan kepada masyarakat dan sebagai bahan pengambilan keputusan dalam rangka perencanaan, pelaksanaan, dan pelaporan pertanggungjawaban pemerintah daerah.

Berdasarkan PP tersebut, pemerintah daerah berkewajiban mengembangkan dan memanfaatkan kemajuan teknologi informasi untuk mempermudah dan mempercepat proses pengelolaan dan pelaporan keuangan guna pengambilan keputusan dalam suatu organisasi (Riawan, 2016). Tujuan penyelenggaraan SIKD diantaranya membantu kepala daerah menyusun anggaran dan laporan pengelolaan keuangan daerah, merumuskan kebijakan keuangan, mengevaluasi kinerja keuangan, menyediakan kebutuhan statistik keuangan, menyajikan informasi secara terbuka kepada masyarakat dan mendukung penyediaan informasi keuangan daerah yang dibutuhkan dalam SIKD nasional. Selanjutnya dalam PP 71 Tahun 2010 menyatakan dalam penyusunan pelaporan keuangan daerah diperlukan sistem yang mengatur proses pengklasifikasian, pengukuran dan pengungkapan seluruh transaksi keuangan yang disebut dengan sistem akuntansi yang diimplementasikan dalam Sistem Informasi Keuangan Daerah. 
Efektivitas penerapan sistem informasi keuangan daerah adalah merupakan bagian dari kesuksesan penerapan sistem informasi keuangan daerah itu sendiri. Istilah efektivitas sistem informasi ditunjukkan oleh ukuran kesuksesan penerapan sistem informasi dalam mencapai tujuan yang telah ditetapkan (William H. DeLone and Ephraime R. McLean, 2003). Menurut (Ismail, 2009) efektivitas sistem informasi akuntansi berkenaan dengan sistems quality, information quality, information use, user satisfaction, individual impact, and organizational impact. Adapun istilah kesuksesan atau keberhasilan sistem informasi akuntansi ditunjukkan oleh ukuran output yang dihasilkan oleh sistem yang sesungguhnya, unuk meningkatkan produktivitas, meningkatkan kinerja dan meningkatkan kontrol atas keputusan yang berkaitan dengan informasi yang dihasilkan oleh sistem informasi akuntansi tersebut (Sari, 2015).

Secara teori ada beberapa model komprehensif yang dapat dirujuk untuk dimensi keberhasilan penerapan sistem informasi akuntansi, antara lain Updated Information Sistem Success Model (William H. DeLone and Ephraime R. McLean, 2003), Hierarchical Structural Model (Farhoomand, 1998) dan (Edition \& Traver, 2012) memberikan lima dimensi untuk mengukur keberhasilan penerapan sistem informasi akuntansi. Dimensi-dimensi tersebut adalah tingkat penggunaan yang tinggi, kepuasan pengguna terhadap sistem, sikap yang positif pengguna terhadap sistem tersebut, tercapainya tujuan sistem informasi dan imbal balik keuangan.

Kerangka pikir teoritis DeLone and McLean (DeLone, 1992) atas efektivitas sebuah sistem informasi dapat dilihat pada gambar berikut ini :

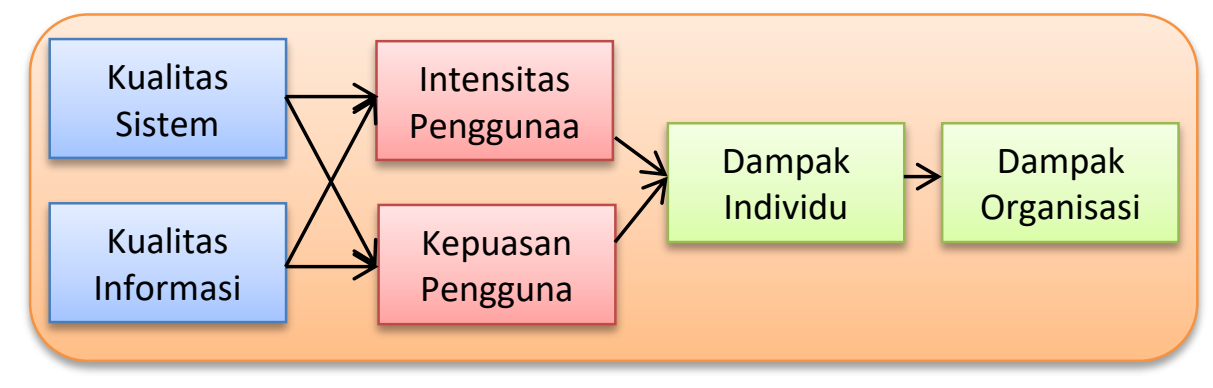

\section{Gambar 1. Model DeLone and McLean}

Dimensi efektivitas sistem informasi pada model DeLone and McLean ditentukan oleh dimensi sebagai berikut :

1) Dimensi kualitas sistem (system quality), berhubungan dengan proses pengukuran sistem itu sendiri yaitu mengukur efektivitas sistem informasi secara teknis. 
Kualitas sistem menunjukkan kualitas produk dari aplikasi sistem informasi. Untuk mengukur kualitas sistem terdiri dari : andal, fleksibel, terintegrasi dan pentingnya sistem.

2) Dimensi kualitas informasi (information quality) yaitu mengukur efektivitas informasi dalam menyampaikan makna yang dimaksud. Indikator yang digunakan adalah akurat, tepat waktu, komplit dan relevan.

3) Dimensi penggunaan sistem, berkaitan dengan semakin baik kualitas sistem dan kualitas output sistem yang diberikan, misalnya dengan cepatnya waktu untuk mengakses, dan kegunaan dari output sistem, akan menyebabkan pengguna tidak merasa enggan untuk melakukan penggunaan kembali (reuse), dengan demikian intensitas penggunaan sistem akan meningkat. Penggunaan yang berulang-ulang ini dapat dimaknai bahwa penggunaan yang dilakukan bermanfaat bagi pengguna. Tingginya derajat manfaat yang diperoleh mengakibatkan pengguna akan lebih puas. Dimensi ini diukur dengan menggunakan istilah frequency of use, time of use, number of accesses, usage pattern, and dependency.

4) Dimensi kepuasan pemakai (user satisfaction) yang merupakan respon pengguna terhadap sistem yang diukur dengan menggunakan istilah self-efiacy, repeat visit, personalization, perceived risk and enjoyment.

5) Dimensi dampak individu (individual impact), mengukur pengaruh sistem terhadap kebiasaan pengguna. Dampak individu merupakan pengaruh dari keberadaan dan penggunaan sistem informasi terhadap kinerja, pengambilan keputusan, dan derajat pembelajaran individu dalam organisasi. Penerapan sistem informasi berdampak pada reaksi yang ditunjukkan oleh perilaku individu dalam organisasi. Secara positif keberadaan sistem informasi akan menjadi rangsangan (stimulus) dan tantangan bagi individu dalam organisasi untuk bekerja secara lebih baik, yang pada gilirannya berdampak pada kinerja organisasi. Sistem dikatakan efektif jika pengguna sistem mendapatkan manfaat seperti produktivitas kinerja individu tersebut.

6) Dimensi dampak organisasi (organizational impact), yaitu mengukur dampak sistem terhadap organisasi, apakah sistem memberi dampak terhadap kinerja perusahaan seperti : cost saving expanded markets, incremental additional sales, reduced search cost, time saving, dan lain-lain. 
Berdasarkan uraian di atas, maka dimensi efektivitas penerapan sistem informasi keuangan daerah dalam penelitian ini adalah sebagai berikut :

1) Dimensi kualitas sistem, berhubungan dengan proses pengukuran sistem itu sendiri. Indikator yang digunakan untuk mengukur kualitas sistem terdiri dari keandalan, fleksibel, terintegrasi, dan pentingnya sistem itu sendiri.

2) Dimensi kualitas informasi, berhubungan dengan kualitas informasi yang dihasilkan oleh sistem. Dimensi ini diukur dengan menggunakan indikator akurat, tepat waktu, komplit dan relevan.

3) Dimensi penggunaan sistem berhubungan dengan keunggulan sistem atas kualitas sistem dan kualitas output sistem yang diberikan yang berkaitan dengan tingkat kemanfaatan yang diperoleh seorang pengguna atas sistem informasi akuntansi.. Dimensi ini diukur dengan menggunakan kualitas pelayanan sistem, kemudahan sistem, kesesuaian sistem.

4) Dimensi kepuasan pemakai (user satisfaction) yang merupakan respon pengguna terhadap sistem. Dimensi ini diukur dengan menggunakan indikator keyakinan diri (self-efiacy), kunjungan berulang (repeat visit), personalisasi (personalization), perceived risk and enjoyment.

5) Dimensi dampak organisasi, merupakan pengaruh keberadaan dan penggunaan sistem informasi terhadap kualitas kinerja organisasi. Variabel dampak organisasi diukur dengan efektivitas informasi dan efisiensi biaya atas sistem itu sendiri yang berdampak terhadap peningkatan kinerja organisasi.

\subsection{Sistem Pengendalian Intern Pemerintah}

Undang-undang di bidang keuangan negara membawa implikasi bahwa sistem pengelolaan keuangan negara yang lebih akuntabel dan transparan sangat diperlukan. Dengan demikian maka penyelenggaraan kegiatan pada suatu Instansi Pemerintah, mulai dari perencanaan, pelaksanaan, pengawasan, sampai dengan pertanggungjawaban, harus dilaksanakan secara tertib, terkendali, serta efisien dan efektif. Untuk itu dibutuhkan suatu sistem yang dapat memberi keyakinan memadai bahwa penyelenggaraan kegiatan pada suatu Instansi pemerintah dapat mencapai tujuannya secara efisien dan efektif, melaporkan pengelolaan keuangan negara secara andal, mengamankan aset negara, dan mendorong ketaatan terhadap peraturan perundang-undangan. 
Sistem ini dikenal sebagai Sistem Pengendalian Intern yang dalam penerapannya harus memperhatikan rasa keadilan dan kepatutan serta mempertimbangkan ukuran, kompleksitas, dan sifat dari tugas dan fungsi Instansi Pemerintah tersebut. Pasal 58 ayat (1) dan ayat (2) Undang-Undang Nomor 1 Tahun 2004 tentang Perbendaharaan Negara memerintahkan pengaturan lebih lanjut ketentuan mengenai sistem pengendalian intern pemerintah secara menyeluruh dengan Peraturan Pemerintah.

Berdasarkan pemikiran bahwa Sistem Pengendalian Intern melekat sepanjang kegiatan, dipengaruhi oleh sumber daya manusia, serta hanya memberikan keyakinan yang memadai, bukan keyakinan mutlak tersebut, dikembangkan unsur Sistem Pengendalian Intern yang berfungsi sebagai pedoman penyelenggaraan dan tolok ukur pengujian efektivitas penyelenggaraan Sistem Pengendalian Intern. Dijelaskan oleh (Mahmudi, 2010) bahwa sistem akuntansi berkaitan erat dengan sistem pengendalian internal organisasi. Sistem akuntansi yang baik adalah sistem akuntansi yang di dalamnya mengandung sistem pengendalian yang memadai. Pengertian sistem pengendalian intern adalah proses yang integral dari tindakan dan kegiatan yang dilakukan oleh manajemen (eksekutif) dan jajarannya untuk memberikan jaminan atau keyakinan yang memadai atas tercapainya tujuan organisasi dalam melalui kegiatan yang efektif dan efisien, keandalan laporan keuangan, pengamanan aset negara, dan ketaatan terhadap peraturan perundangundangan.

Sistem Pengendalian Intern Pemerintah, yang selanjutnya disingkat SPIP, adalah Sistem Pengendalian Intern yang diselenggarakan secara menyeluruh di lingkungan pemerintah pusat dan pemerintah daerah. Menurut Peraturan Pemerintah Nomor 60 Tahun 2008 (Indonesia, 2008) tentang Sistem Pengendalian Intern Pemerintah dijelaskan bahwa Sistem Pengendalian Internal adalah proses yang integral pada tindakan dan kegiatan yang dilakukan secara terus menerus oleh pimpinan dan seluruh pegawai untuk memberikan keyakinan memadai atas tercapainya tujuan organisasi melalui kegiatan yang efektif dan efisien, keandalan pelaporan keuangan, pengamanan aset negara, dan ketaatan terhadap peraturan perundang-undangan. Selanjutnya dalam Peraturan Pemerintah tersebut juga menjelaskan bahwa komponen-komponen sistem pengendalian intern pemerintah adalah sebagai berikut : 
1) Lingkungan pengendalian.

Lingkungan pengendalian menetapkan corak organisasi, mempengaruhi kesadaran pengendalian orang-orangnya. Lingkungan pengendalian merupakan dasar untuk semua komponen pengendalian intern, menyediakan disiplin dan struktur. Lingkungan pengendalian mencakup sebagai berikut :

a) Integritas dan nilai etika

b) Komitmen terhadap kompetensi

c) Filosofi dan gaya operasi manajemen

d) Struktur organisasi

e) Pemberian wewenang dan tanggung jawab

f) Kebijakan dan praktik sumber daya manusiaPeran aparat pengawasan intern pemerintah yang efektif

g) Hubungan kerja yang baik dengan instansi pemerintah terkait

2) Penilaian risiko

Penilaian risiko adalah identifikasi entitas dan analisis terhadap risiko yang relevan untuk mencapai tujuannya, membentuk suatu dasar untuk menentukan bagaimana risiko harus dikelola. Risiko yang relevan dengan pelaporan keuangan mencakup peristiwa dan keadaamn intern maupun ekstern yang dapat terjadi dan secara negatif mempengaruhi kemampuan entitas untuk mencatat, mengolah, meringkas dan melaporkan data keuangan konsisten dengan asersi manajemen dalam laporan keuangan. Penilaian risiko mencakup sebagai berikut :

a) Pengidentifikasian risiko

b) Analisis risiko

c) Pengelolaan risiko

3) Kegiatan pengendalian

Kegiatan pengendalian adalah kebijakan dan prosedur yang membantu menjamin bahwa arahan manajemen dilaksanakan. Kegiatan tersebut membantu memastikan bahwa tindakan yang diperlukan untuk menanggulangi risiko dalam pencapaian tujuan entitas. Umumnya kegiatan 
pengendalian yang mungkin relevan dengan audit dapat digolongkan sebagai kebijakan dan prosedur yang berkaitan dengan perihal berikut :

a) Review terhadap kinerja

b) Pengolahan informasi

c) Pengendalian fisik

d) Pemisahan tugas

e) Pencatatan dan dokumentasi

4) Informasi dan komunikasi

Informasi dan komunikasi adalah pengidentifikasian, penangkapan, dan pertukaran informasi dalam suatu bentuk dan waktu yang memungkinkan orang yang melaksanakan tanggung jawab mereka. Sistem informasi yang relevan dengan tujuan pelaporan keuangan yang meliputi sistem akuntansi dan untuk memelihara akuntabilitas bagi aktiva, utang dan ekuitas yang bersangkutan. Komunikasi mencakup penyediaan suatu pemahaman tentang peran dan tanggung jawab individual berkaitan dengan pengendalian intern terhadap pelaporan keuangan. Pengetahuan memadai tentang sistem informasi yang relevam dengan pelaporan keuangan harus diperoleh untuk memahami :

a) Golongan transaksi dalam operasi entitas yang signifikasn bagi laporan keuangan

b) Bagaimana transaksi tersebut dimulai

c) Catatan akuntansi, informasi pendukung, dan akun tertentu dalam laporan keuangan yang tercakup dalam pengolahan dan pelaporan transaksi.

d) Pengolahan akuntansi yang dicakup sejak saat transaksi dimulai sampai dengan dimasukkan ke data laporan keuangan, termasuk alat elektronik yang digunakan untuk mengirim, memproses, memelihara dan mengakses informasi.

5) Pemantauan pengendalian intern.

Pemantauan adalah proses penentuan kualitas kinerja pengendalian intern sepanjang waktu. Pemantauan ini mencakup penentuan desain dan operasi pengendalian tepat waktu dan pengambilan tindakan koreksi. 
Aktivitas pemantau auditor intern atau personel yang dapat memberikan petunjuk tentang masalah atau bidang yang memerlukan perhatian.

Berdasarkan uraian di atas maka dapat disimpulkan bahwa sistem pengendalian intern pemerintah adalah suatu proses yang integral yang dipengaruhi oleh pimpinan dan seluruh pegawai untuk memberikan keyakinan memadai atas tercapainya tujuan organisasi melalui kegiatan yang efektif dan efisien, keandalan pelaporan keuangan, pengamanan aset negara dan ketaatan terhadap peraturan perundang-undangan yang terdiri dari berbagai komponen-komponen yang telah diuraikan di atas yaitu : lingkungan pengendalian, penilaian risiko, pengendalian aktivitas, sistem informasi dan komunikasi, serta pemantauan (Indonesia, 2008).

\subsection{Ketersediaan Anggaran}

Anggaran adalah suatu alat perencanaan dan pengendalian yang efektif di dalam organisasi, yang bersifat jangka pendek biasanya mencakup periode satu tahun (Anthony, N. Robert dan Govindarajan, 2011). Menurut (Kaho, 2010) salah satu faktor yang sangat mempengaruhi dan sangat menentukan penyelenggaraan otonomi daerah, selain Sumber Daya Manusia dan Kemampuan aparatur adalah keuangan yang stabil dan peralatan yang lengkap.

Governmental Accounting Standard Board menyatakan bahwa anggaran merupakan rencana operasi keuangan yang mencakup estimasi pengeluaran yang diusulkan dan sumber pendapatan yang diharapkan untuk membiayainya dalam periode waktu tertentu. Selanjutnya (Supriyono, 1987) mengungkapkan bahwa anggaran adalah suatu rencana terinci yang dinyatakan secara formal dalam ukuran kuantitatif untuk menunjukkan bagaimana sumber sumber akan diperoleh dan akan digunakan selama jangka waktu tertentu, umumnya satu tahun. Kegiatan penyusunan anggaran ini dinamakan anggaran memiliki dua peran penting di dalam sebuah organisasi, yaitu pertama berperan sebagai alat perencanaan dan kedua berperan sebagai alat pengendalian.

Sebagai sebuah rencana tindakan, anggaran dapat digunakan sebagai alat untuk mengendalikan kegiatan organisasi atau unit organisasi dengan cara membandingkan hasil yang sesungguhnya yang dicapai dengan rencana yang telah ditetapkan. Dalam hal ini pengelolaan sumber daya yang dimiliki organisasi meliputi sumber daya finansial, fisik, SDM, dan kemampuan teknologis dan sistem. 
Anggaran adalah pernyataan mengenai estimasi kinerja yang hendak dicapai selama periode waktu tertentu yang dinyatakan dalam ukuran finansial (Mardiasmo, n.d.). Dengan demikian, setiap organisasi perlu proses perencanaan dalam menyiapkan anggaran karena proses tersebut sangat penting untuk mendukung pelaksanaan kegiatannya selama satu tahun anggaran dan dalam pelaksanaannya harus efisien, efektif, dan ekonomis serta sesuai dengan peraturan perundang-undangan. Selanjutnya (Mardiasmo, n.d.) menyatakan bahwa anggaran harus:

1) Anggaran daerah harus bertumpu pada kepentingan publik.

2) Adanya kejelasan tentang misi pengelolaan keuangan daerah pada umumnya dan anggaran daerah pada khususnya, yang berarti alokasi APBD harus jelas dan menggambarkan dukungan alokasi anggaran bagi daerah guna mengemban misinya dari tahun ke tahun menuju tujuan strategis daerah.

3) Desentralisasi pengelolaan keuangan daerah dan kejelasan para pihak yang terkait dengan pengelolaan keuangan daerah untuk mewujudkan mekanisme check and balance.

4) Kerangka hukum dan administrasi bagi pembiayaan, investasi dan pengelolaan uang daerah berdasarkan kaidah mekanisme pasar, value for money, transparansi dan akuntabilitas.

5) Kejelasan tentang kedudukan keuangan DPRD, dan PNS daerah baik rasio dan dasar pertimbangannya.

6) Kejelasan tentang bentuk dan struktur anggaran kinerja dan anggaran multi tahun yang diharapkan lebih mendorong keterbukaan dan kecepatan penyajian laporan keuangan daerah.

7) Pinsip pengadaan dan pengelolaan barang daerah yang lebih profesional, karena dalam realisasi APBD sering mengakibatkan penambahan keuangan daerah.

8) Standard dan sistem akuntan keuangan daerah, laporan keuangan daerah, diperlukan peranan akuntan independen dalam pemeriksaan, pemberian opini dan rating kinerja anggaran dapat mendorong percepatan internalisasi akuntasi dalam anggaran.

9) Aspek pembinaan dan pengawasan guna pengembangan profesionalisme 
aparat pemerintah, dan

10) Pengembangan sistem informasi keuangan daerah. Semua aspek di atas, tidak dilaksanakan secara parsial, namun terpadu bila ingin mewujudkan reformasi pengelolaan keuangan daerah.

Faktor ketersediaan anggaran (financial) menjadi suatu hal yang penting dalam meningkatkan kinerja yang berkaitan dengan pelaksanaan tugas untuk mencapai tujuan dan meningkatkan profesionalisme hasil kerja. Penelitian tentang ketersediaan anggaran belum banyak dilakukan oleh peneliti terdahulu. Salah satu penelitian tentang ketersediaan anggaran (Idris, 2013) mengemukakan bahwa ketersediaan anggaran dalam pelayanan, akan memberikan kontribusi yang signifikan terhadap kinerja pelayanan aparatur. Adapun indikator dan dimensi ketersediaan anggaran menurut (Idris, 2013) adalah sebagai berikut:

1) Dimensi sumber anggaran, dengan indikator : APBN, APBD Provinsi,APBD Kota/Kabupaten

2) Dimensi alokasi anggaran, dengan indikator : alokasi perencanaan, alokasi sosialisasi, alokasi pelaksanaan, dan alokasi pengendalian

3) Dimensi kemampuan pengelolaan anggaran, dengan indikator : tujuan program yang jelas, standar prosedur yang jelas, indikator kinerja, berdasarkan perkiraan dan proyeksi, terdapat control dan evaluasi, terdapat transparansi dan akuntabilitas, efisensi dan efektivitas.

Berdasarkan uraian di atas maka dimensi ketersediaan anggaran pada penelitian ini terdiri dari : dimensi sumber anggaran dengan indikator APBN, APBD Provinsi, APBD Kabupaten/Kota, dimensi alokasi anggaran dengan indikator alokasi perencanaan, alokasi sosialisasi, alokasi pelaksanaan, dan alokasi pengendalian, dimensi kemampuan pengelolaan anggaran dengan indikator tujuan program yang jelas, standar prosedur yang jelas, indikator kinerja.

\subsection{Pengembangan Hipotesis}

\section{Kerangka Konseptual}

Kerangka konseptual dalam penelitian ini terkait dengan pengaruh sistem pengendalian intern pemerintah dan ketersediaan anggaran terhadap efektivitas penerapan Sistem Informasi Keuangan Daerah. 


\section{a. Pengaruh Sistem Pengendalian Intern Pemerintah Terhadap Efektivitas Penerapan Sistem Informasi Keuangan Daerah.}

Pengendalian diperlukan di dalam sistem agar sistem dapat berfungsi sesuai dengan yang diharapkan dalam mencapai suatu tujuan (Susanto, 2008). Sistem informasi akuntansi dengan pengendalian internal harus berjalan beriringan dalam suatu perusahaan, sistem informasi akuntansi yang berlaku berisi berbagai metode dan prosedur harus mendukung terciptanya kegiatan struktur pengendalian intern (Huda, Ekawati, \& Pratiwi, 2017). Sistem informasi akuntansi dapat diterapkan dengan efektif jika di dalam sistem tersebut juga dibangun sistem pengendalian internal. Menurut (Alvin A. Arens, Randal J. Elder, 2010) menyatakan bahwa perusahaan diharuskan untuk mengembangkan pengendalian internal dengan tujuan untuk memberikan kepastian yang layak bahwa laporan keuangan disajikan secara wajar. Sistem pengendalian internal memiliki lima komponen yaitu : 1) lingkungan pengendalian, 2) penilaian risiko, 3) aktivitas pengendalian, 4) informasi dan komunikasi, dan 5) pemantauan (Alvin A. Arens, Randal J. Elder, 2010; Indonesia, 2008).

Kelima komponen ini terbangun dalam insfrastruktur sistem informasi akuntansi yang disebut dengan sistem informasi keuangan daerah sehingga tujuan dari sistem informasi tersebut dapat tercapai. Sistem pengendalian intern akan sangat efektif bila pengendalian tersebut menyatu dengan infrastruktur dan merupakan bagian penting dari organisasi (Susanto, 2008). Untuk pengembangan sebuah sistem informasi diperlukan pengendalian internal, karena tanpa pengendalian internal yang tepat akan dapat mengakibatkan ketidakakuratan dan ketidakefisienan sistem informasi (Bae, Epps, \& Gwathmey, 2003).

Beberapa penelitian terkait menyatakan bahwa terdapat pengaruh sistem pengendalian intern terhadap efektivitas sistem informasi akuntansi. Dalam penelitian (Huda et al., 2017) pada Perusahaan BUMN di Kota Palembang menyatakan bahwa sistem informasi akuntansi berpengaruh terhadap pengendalian internal. Ketersediaan sistem informasi akuntansi yang baik akan membantu manajemen mengendalikan sebuah organisasi bisnis. Penelitian yang sama pada BUMN yang berada di Jawa Barat (Kurniawan, 2017) menyatakan bahwa pengendalian internal berpengaruh terhadapkualitas sistem informasi akuntansi, betapa pentingnya pengendalian internal untuk menghasilkan sistem informasi akuntansi yang berkualitas sehingga menghasilkan 
informasi akuntansi yang berkualitas pula. Selanjutnya hasil penelitian yang dilakukan pada pemerintah daerah, (Sari, 2015) menyatakan bahwa sistem pengendalian intern pemerintah berpengaruh terhadap kesuksesan penerapan sistem informasi akuntansi.

\section{b. Pengaruh Ketersediaan Anggaran Terhadap Efektivitas Sistem Informasi Keuangan Daerah}

Anggaran merupakan rencana keuangan masa mendatang yang mencakup harapan manajemen terhadap pendapatan, biaya dan transaksi keuangan lain dalam masa satu tahun. Anggaran organisasi publik mencakup rencana-rencana tentang berapa biaya atas rencana yang dibuat dan berapa banyak serta bagaimana cara memperoleh uang untuk mendanai rencana tersebut. Anggaran merupakan salah satu pilar dalam perencanaan pembangunan bagi pemerintah (Ayuni \& Erawati, 2018).

Salah satu karakteristik anggaran adalah kejelasan sasaran anggaran. Kejelasan sasaran anggaran juga berimplikasi pada aparatur pemerintah untuk menyusun sasaran yang ingin dicapai instansi pemerintah, sehingga aparatur pemerintah memiliki informasi yang cukup untuk memprediksi masa depan secara cepat (Ayuni \& Erawati, 2018). Untuk membangun sebuah sistem informasi keuangan tidak terlepas dari ketersediaan anggaran. Tetapi pengalokasian pengganggaran belanja pada pemerintah daerah yang terjadi saat ini lebih dominan kepada belanja pegawai. Sumber-sumber penerimaan yang dimiliki oleh pemerintah bersifat terbatas, sehingga dituntut mampu memberdayakan dan mengoptimalkan penggunaan anggaran yang ada untuk hasil yang optimal.

Penelitian tentang pengaruh ketersediaan anggaran terhadap efektivitas sistem informasi keuangan daerah belum banyak dilakukan. Adapun penelitian yang terkait dengan ketersediaan anggaran dilakukan oleh (Idris, 2013), pada SKPD di Kabupaten Aceh Utara menyatakan bahwa terdapat pengaruh langsung variabel ketersediaan anggaran dan jiwa kewirausahaan terhadap kinerja pelayanan aparatur.

\section{c. Pengaruh Sistem Pengendalian Intern Pemerintah dan Ketersediaan Anggaran Terhadap Efektivitas Penerapan Sistem Informasi Keuangan Daerah}

Sistem pengendalian internal pemerintah dalam organisasi sektor publik adalah alat untuk mencegah terjadinya pemborosan anggaran yang tidak perlu dilakukan dalam 
segala aspek dan untuk mengurangi penggunaan sumber daya yang tidak efisien. (Rusvianto, Mulyani, \& Yuliafitri, n.d.) Anggaran diharapkan dapat dipergunakan untuk menjalankan program atau kegiatan yang telah dibuat secara efektif, efisien, dan ekonomis. Oleh karena itu, diperlukan pengendalian dari tingkat atas sampai tingkat bawah, dalam rangka mencapai tujuan dan sasaran organisasi yang telah ditetapkan serta dapat dipertanggungjawabkan kepada publik atau masyarakat (Nurhayati, 2013).

Sistem akuntansi Pemerintah sesuai dengan Peraturan Pemerintah (PP) No. 71 Tahun 2010 pasal 1 angka 11 adalah adalah rangkaian sistematik dari prosedur, penyelenggara, peralatan, dan elemen lain untuk mewujudkan fungsi akuntansi sejak analisis transaksi sampai dengan pelaporan keuangan di lingkungan organisasi pemerintah. Dari sisi eksternal, laporan merupakan komponen penting untuk menciptakan akuntabilitas sektor publik dan salah satu alat untuk penilaian kinerja unit. Sementara itu, dari sisi internal, laporan merupakan dasar untuk mengambil keputusan. Untuk mendapatkan nilai informasi yang baik dan berkualitas dalam laporan keuangan tidak hanya diperlukan sistem pengendalian internal yang harus berjalan dengan baik dalam pemerintahan itu sendiri tetapi harus didukung dengan sistem akuntansi yang baik. Oleh karena itu sistem akuntansi memerlukan pengendalian intern atau dengan kata lain sistem akuntansi berkaitan erat dengan pengendalian intern organisasi (Mahmudi, 2010).

Dari berbagai uraian di atas, keterkaitan antar variabel dalam penelitian ini secara ringkas dapat dilihat melalui kerangka konseptual seperti yang ditampilkan berikut ini :

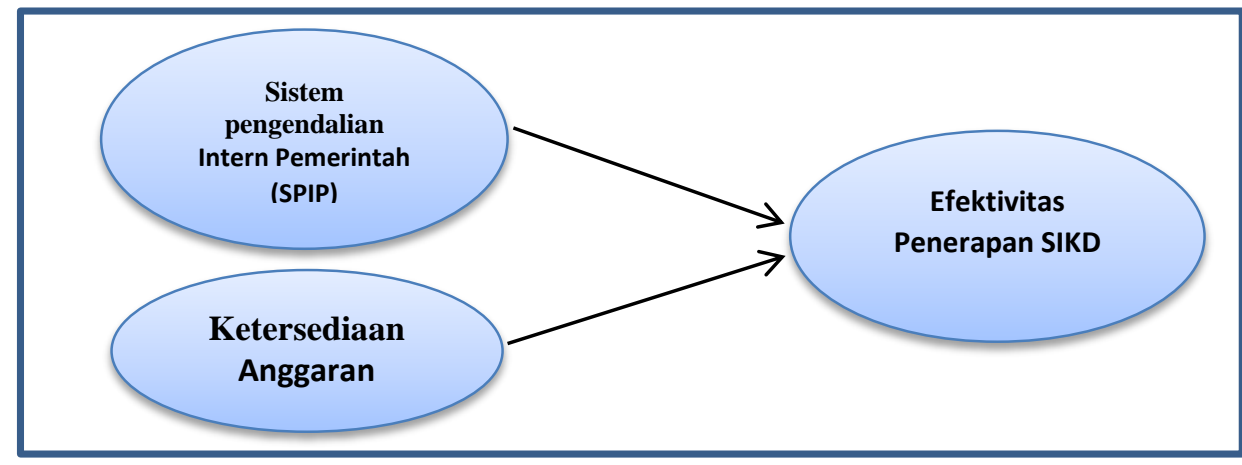

Gambar 2. Hubungan Antar Variabel dalam Penelitian

\section{Hipotesis}

Berdasarkan kerangka konsep tersebut di atas, maka hipotesis yang diajukan dalam penelitian ini adalah : 
a. Sistem pengendalian intern pemerintah berpengaruh terhadap efektivitas penerapan sistem informasi keuangan daerah.

b. Ketersediaan anggaran berpengaruh terhadap efektivitas penerapan sistem informasi keuangan daerah.

c. Sistem pengendalian intern pemerintah dan ketersediaan anggaran secara bersamasama berpengaruh terhadap efektivitas penerapan sistem informasi keuangan daerah.

\section{METODE PENELITIAN}

\subsection{Pemilihan dan Pengumpulan Data}

Penelitian ini adalah penelitian asosiatif dengan menggunakan metode deskriptif kuantitatif yang menekankan pada pengujian teori melalui pengukuran variabel berupa angka-angka yang selanjutnya dilakukan analisis dengan menggunakan prosedur statistik. Penelitian dilakukan untuk mengetahui bagaimana pengaruh sistem pengendalian intern pemerintah dan ketersediaan anggaran terhadap efektivitas penerapan sistem informasi keuangan daerah.

Penelitian ini akan dilakukan di provinsi Sumatera Utara yang terdiri dari 1 Provinsi dan 33 Kabupaten/Kota. Yang menjadi populasi dalam penelitian ini adalah seluruh Pemerintah Daerah di Provinsi Sumatera Utara. Jenis teknik sampling yang digunakan dalam penelitian ini adalah sampling jenuh. Sampling jenuh adalah teknik penentuan sampel bila semua anggota populasi digunakan sebagai sampel. Hal ini dilakukan karena jumlah populasinya relatif kecil, yaitu sebanyak 34 pemerintah daerah, sehingga semua anggota populasi dijadikan sampel.

Teknik pengumpulan data yang digunakan dalam penelitian ini adalah dengan menggunakan data primer. Data primer dikumpulkan secara langsung dari sumbernya, yakni data yang diperoleh dari responden melalui kuesioner yang berisi daftar pertanyaan atau pernyataan terstruktur mengenai hal yang berkaitan dengan variabel yang digunakan dalam penelitian.yang ditujukan kepada Pejabat Pengelola Keuangan Daerah (PPKD) dan Inspektorat Daerah di Kabupaten/Kota se-Sumatera Utara.

\subsection{Pengukuran dan Defenisi Operasional Variabel Penelitian}

Penelitian ini terdiri atas satu variabel endogen yaitu efektivitas penerapan sistem informasi keuangan daerah $\left(\mathrm{y}_{1}\right)$, dengan dua variabel eksogen yang terdiri atas sistem 
pengendalian intern pemerintah $\left(\mathrm{x}_{1}\right)$ dan ketersediaan anggaran $\left(\mathrm{x}_{2}\right)$. Untuk selanjutnya dimensi dalam setiap variabel tersebut dijabarkan dalam kuesioner yang kemudian disebarkan kepada responden. Data yang dikumpulkan melalui penyebaran kuesioner tersebut untuk selanjutnya digunakan skala likert untuk menjawab kuesioner dimaksud. Dalam pengukurannya, setiap responden diminta pendapatnya mengenai suatu pertanyaan dengan skala penilaian sebagai berikut :

\section{Tabel 2}

Bobot Skala Likert

\begin{tabular}{|l|c|}
\hline \multicolumn{1}{|c|}{ Kategori Jawaban Pertanyaan/Pernyataan } & Skala Likert \\
\hline Tidak Memadai / Tidak Baik / Tidak Setuju & 1 \\
\hline Kurang Memadai / Kurang Baik / Kurang Setuju & 2 \\
\hline Cukup Memadai / Cukup Baik / Cukup Setuju & 3 \\
\hline Memadai / Baik / Setuju & 4 \\
\hline Sangat Memadai / Sangat Baik / Sangat Setuju & 5 \\
\hline
\end{tabular}

Sumber : (Sugiyono, 2010)

Data yang dikumpulkan melalui kuesioner selanjutnya dilakukan pengujian terlebih dahulu yang meliputi uji validitas (test of validity) dan uji reliabilitas (test of reliability). Variabel-variabel yang digunakan dalam penelitian tersebut dijelaskan dalam tabel defenisi operasional sebagai berikut:

Tabel 3

\section{Definisi Operasional}

\begin{tabular}{|c|c|c|c|}
\hline Variabel & Dimensi & Indikator & Skala \\
\hline \multirow[t]{2}{*}{$\begin{array}{l}\text { Sistem } \\
\text { pengendalian } \\
\text { Intern Pemerintah } \\
\left(x_{1}\right) \\
\text { (Indonesia, 2008) }\end{array}$} & $\begin{array}{l}\text { Lingkungan } \\
\text { Pengendalian }\end{array}$ & $\begin{array}{l}\text { 1. Integritas dan nilai etika } \\
\text { 2. Komitmen terhadap kompetensi } \\
\text { 3. Filosofi dan gaya operasi } \\
\text { manajemen } \\
\text { 4. Struktur Organisasi } \\
\text { 5. Pemberian wewenang dan } \\
\text { tanggung jawab } \\
\text { 6. Kebijakan dan praktik sumber daya } \\
\text { manusia } \\
\text { 7. Peran aparat pengawasan yang } \\
\text { efektif } \\
\text { 8. Hubungan kerja yang baik dengan } \\
\text { pemerintah terkait }\end{array}$ & Interval \\
\hline & $\begin{array}{l}\text { Penilaian } \\
\text { risiko }\end{array}$ & $\begin{array}{l}\text { 1. Identifikasi risiko } \\
\text { 2. Analisis risiko } \\
\text { 3. Pengelolaan risiko }\end{array}$ & Interval \\
\hline
\end{tabular}




\begin{tabular}{|c|c|c|c|}
\hline Variabel & Dimensi & Indikator & Skala \\
\hline \multirow{3}{*}{$\begin{array}{l}\text { Sistem } \\
\text { pengendalian } \\
\text { Intern Pemerintah } \\
\left(x_{1}\right) \\
\text { (Indonesia, 2008) }\end{array}$} & $\begin{array}{l}\text { Pengendalian } \\
\text { Aktivitas }\end{array}$ & $\begin{array}{l}\text { 1. Review terhadap kinerja } \\
\text { 2. Pengolahan informasi } \\
\text { 3. Pengendalian fisik } \\
\text { 4. Pemisahan tugas } \\
\text { 5. Pencatatan dan dokumentasi }\end{array}$ & Interval \\
\hline & $\begin{array}{l}\text { Sistem } \\
\text { informasi dan } \\
\text { komunikasi }\end{array}$ & $\begin{array}{l}\text { 1. Menyediakan dan memanfaatkan } \\
\text { berbagai bentuk sarana komunikasi } \\
\text { 2. Mengelola, mengembangkan dan } \\
\text { memperbarui informasi secara terus } \\
\text { menerus }\end{array}$ & Interval \\
\hline & Pemantauan & $\begin{array}{l}\text { 1. Pemantauan berkelanjutan } \\
\text { 2. Evaluasi terpisah } \\
\text { 3. Tindak lanjut rekomendasi hasil audit } \\
\text { dan reviu lainnya }\end{array}$ & Interval \\
\hline
\end{tabular}

\subsection{Metode Analisis Data}

Analisis data teknik yang digunakan dalam penelitian ini adalah analisis regresi menggunakan SPSS versi 25 dengan tingkat signifikansi sebesar 5\%. Sebelum pengujian hipotesis, dilakukan uji asumsi klasik dan selanjutnya dilakukan pengujian hipotesis menggunakan analisis regresi linier berganda.

\section{HASIL DAN DISKUSI}

\subsection{Hasil Analisis Data}

Berdasarkan hasil penelitian maka di dapatkan hasil pengolahan data yang diperoleh dari pengolahan kuesioner dengan menggunakan uji asumsi klasik dan analisis regresi linear berganda yaitu sebagai berikut :

\section{Uji Normalitas}

\section{Tabel 4}

Hasil Uji Normalitas

\begin{tabular}{|l|l|r|}
\hline \multicolumn{2}{|c|}{ One-Sample Kolmogorov-Smirnov Test } \\
\hline \multicolumn{2}{|l|}{} & \multicolumn{1}{|c|}{$\begin{array}{c}\text { Unstandardized } \\
\text { Residual }\end{array}$} \\
\hline $\mathrm{N}$ & Mean & .0000000 \\
\hline Normal Parameters & a,b & $\begin{array}{l}\text { Std. } \\
\text { Deviation }\end{array}$ \\
\hline
\end{tabular}




\begin{tabular}{|l|l|r|}
\hline $\begin{array}{l}\text { Most Extreme } \\
\text { Differences }\end{array}$ & Absolute & .079 \\
\hline & Positive & .055 \\
\cline { 2 - 3 } & Negative & -.079 \\
\hline Test Statistic & .079 \\
\hline Asymp. Sig. (2-tailed) & $.200^{\mathrm{c}, \mathrm{d}}$ \\
\hline \multicolumn{2}{|l|}{ Test distribution is Normal. } \\
\hline \multicolumn{2}{|l|}{ Calculated from data. } \\
\hline \multicolumn{2}{|l|}{ Lilliefors Significance Correction. } \\
\hline \multicolumn{2}{|l}{ This is a lower bound of the true significance. } \\
\hline
\end{tabular}

Sumber : Output SPSS

Dari tabel di atas dapat terlihat nilai unstandardized Sig. (2-tailed) untuk keseluruhan variabel keseluruhan 0,200 > 0,05. Dengan demikian dapat dinyatakan bahwa nilai residual berdistribusi normal.

\section{a. Uji Multikolinieritas}

Tabel 5

Hasil Uji Multikolinieritas

\begin{tabular}{|c|c|c|c|c|c|c|c|c|}
\hline \multicolumn{9}{|c|}{ Coefficients $^{\mathrm{a}}$} \\
\hline & & \multicolumn{2}{|c|}{$\begin{array}{l}\text { Unstandardized } \\
\text { Coefficients }\end{array}$} & \multirow{2}{*}{$\begin{array}{c}\begin{array}{c}\text { Standardized } \\
\text { Coefficients }\end{array} \\
\text { Beta }\end{array}$} & \multirow[b]{2}{*}{$\mathrm{t}$} & \multirow[b]{2}{*}{ Sig. } & \multicolumn{2}{|c|}{ Collinearity Statistics } \\
\hline \multicolumn{2}{|c|}{ Model } & B & Std. Error & & & & Tolerance & VIF \\
\hline \multirow[t]{3}{*}{1} & (Constant) & 67.987 & 14.438 & & 4.709 & .000 & & \\
\hline & SPIP & .110 & .084 & .159 & 1.307 & .196 & .893 & 1.119 \\
\hline & $\begin{array}{l}\text { Ketersediaan } \\
\text { Anggaran }\end{array}$ & 480 & .200 & .292 & 2.404 & .019 & .893 & 1.119 \\
\hline
\end{tabular}

a. Dependent Variable: Efektivitas SIKD

\section{Sumber : Output SPSS}

Berdasarkan tabel di atas Variance Inflation Factor (VIF) variabel Sistem Pengendalian Internal Pemerintah $\left(\mathrm{SPIP} / \mathrm{X}_{1}\right)$ sebesar 1,119, variabel ketersediaan anggaran $\left(\mathrm{KA} / \mathrm{X}_{2}\right)$ sebesar 1,199. Dengan demikian Variance Inflation Factor (VIF) seluruhnya lebih kecil dari 10, maka pada model regresi yang terbentuk tidak terjadi gejala multikolinier.

\section{b. Uji Heterokedasitas}

Berdasarkan tabel di bawah, terlihat bahwa model regresi tidak terjadi gejala heteroskedastistas. Hal ini disebabkan Sig. variabel Sistem Pengendalian Internal Pemerintah $\left(\mathrm{SPIP} / \mathrm{X}_{1}\right)$ terhadap absolut residual sebesar 0,124 >0,05, Sig. 
Variabel ketersediaan anggaran $\left(\mathrm{KA} / \mathrm{X}_{2}\right)$ terhadap absolut residual sebesar $0,112>$ 0,05 , atau dapat dikatakan nilai signifikansi lebih besar dari nilai alpha $(\operatorname{Sig},>\alpha)$.

Tabel 6

Hasil Uji Heterokedasitas

\begin{tabular}{|c|c|c|c|c|c|c|c|c|}
\hline \multicolumn{9}{|c|}{ Coefficients $^{\mathbf{a}}$} \\
\hline & & \multicolumn{2}{|c|}{$\begin{array}{c}\text { Unstandardized } \\
\text { Coefficients }\end{array}$} & \multirow{2}{*}{$\begin{array}{c}\text { Standardized } \\
\text { Coefficients } \\
\text { Beta }\end{array}$} & \multirow[b]{2}{*}{$\mathrm{t}$} & \multirow[b]{2}{*}{ Sig. } & \multicolumn{2}{|c|}{ Collinearity Statistics } \\
\hline \multicolumn{2}{|c|}{ Model } & B & $\begin{array}{l}\text { Std. } \\
\text { Error }\end{array}$ & & & & Tolerance & VIF \\
\hline \multirow[t]{3}{*}{1} & (Constant) & 29.006 & 8.251 & & 3.516 & .001 & & \\
\hline & SPIP & -.075 & .048 & -.194 & -1.559 & .124 & .893 & 1.119 \\
\hline & $\begin{array}{l}\text { Ketersediaa } \\
\text { n Anggaran }\end{array}$ & -.184 & .114 & -.200 & -1.610 & .112 & .893 & 1.119 \\
\hline
\end{tabular}

a. Dependent Variable: RES2

Sumber : Output SPSS

\section{d. Persamaan Regresi Linear Berganda}

\section{Tabel 7}

\section{Hasil Analisis Regresi Linier Berganda}

\begin{tabular}{|c|c|c|c|c|c|c|c|c|}
\hline \multicolumn{9}{|c|}{ Coefficients $^{\mathbf{a}}$} \\
\hline \multirow{2}{*}{\multicolumn{2}{|c|}{ Model }} & \multicolumn{2}{|c|}{$\begin{array}{l}\text { Unstandardized } \\
\text { Coefficients }\end{array}$} & \multirow{2}{*}{$\begin{array}{c}\text { Standardized } \\
\text { Coefficients } \\
\text { Beta }\end{array}$} & \multirow[b]{2}{*}{$\mathrm{t}$} & \multirow[b]{2}{*}{ Sig. } & \multicolumn{2}{|c|}{ Collinearity Statistics } \\
\hline & & B & Std. Error & & & & Tolerance & VIF \\
\hline \multirow[t]{3}{*}{1} & (Constant) & 67.987 & 14.438 & & 4.709 & .000 & & \\
\hline & SPIP & .110 & .084 & .159 & 1.307 & .196 & .893 & 1.119 \\
\hline & $\begin{array}{l}\text { Ketersediaan } \\
\text { Anggaran }\end{array}$ & .480 & .200 & .292 & 2.404 & .019 & .893 & 1.119 \\
\hline
\end{tabular}

Sumber : Output SPSS

Persamaan Regresi Linear Berganda :

Efektivitas Penerapan Sistem Informasi Keuangan Daerah:

$$
67.987+0.159 \text { SPIP + 0.292 KA }
$$

SPIP : Sistem Pengendalian Intern Pemerintah

KA : Ketersediaan Anggaran 
e. Uji Hipotesis Parsial (Uji t)

\section{Tabel 8}

\section{Hasil Uji t}

\begin{tabular}{|c|c|c|c|c|c|c|c|c|}
\hline \multicolumn{9}{|c|}{ Coefficients $^{\mathbf{a}}$} \\
\hline \multirow{2}{*}{\multicolumn{2}{|c|}{ Model }} & \multicolumn{2}{|c|}{$\begin{array}{l}\text { Unstandardized } \\
\text { Coefficients }\end{array}$} & \multirow{2}{*}{$\begin{array}{l}\text { Standardized } \\
\text { Coefficients } \\
\text { Beta }\end{array}$} & \multirow[b]{2}{*}{$\mathrm{t}$} & \multirow[b]{2}{*}{ Sig. } & \multicolumn{2}{|c|}{ Collinearity Statistics } \\
\hline & & B & Std. Error & & & & Tolerance & VIF \\
\hline \multirow[t]{3}{*}{1} & (Constant) & 67.987 & 14.438 & & 4.709 & .000 & & \\
\hline & SPIP & .110 & .084 & .159 & 1.307 & .196 & .893 & 1.119 \\
\hline & $\begin{array}{l}\text { Ketersediaan } \\
\text { Anggaran }\end{array}$ & .480 & .200 & .292 & 2.404 & .019 & .893 & 1.119 \\
\hline
\end{tabular}

Sumber : Output SPSS

1) Hipotesis 1 (Pengaruh sistem pengendalian internal pemerintah terhadap efektivitas penerapan sistem informasi keuangan daerah, $t$ hitung $(1,307)<\mathrm{t}$ tabel $(1,996)$ dengan taraf signifikansi $0.196>0.05$, maka Ho diterima dan Ha ditolak, artinya tidak ada pengaruh antara sistem pengendalian internal pemerintah terhadap efektivitas penerapan sistem informasi keuangan daerah.

2) Hipotesis 2 (Pengaruh ketersediaan anggaran terhadap efektivitas penerapan sistem informasi keuangan daerah), $\mathrm{t}$ hitung $(2,404)>\mathrm{t}$ tabel $(1,996)$ dengan taraf signifikansi $0.019<0.05$, maka Ho ditolak dan Ha diterima, artinya ada pengaruh antara ketersediaan anggaran terhadap efektivitas penerapan sistem informasi keuangan daerah.

\section{f. Uji Hipotesis Simultan (Uji F)}

Tabel 9

Hasil Uji F

\begin{tabular}{|c|c|c|c|c|c|c|}
\hline \multicolumn{7}{|c|}{ ANOVA $^{a}$} \\
\hline \multicolumn{2}{|c|}{ Model } & Sum of Squares & df & Mean Square & $\mathrm{F}$ & Sig. \\
\hline \multirow[t]{3}{*}{1} & Regression & 757.208 & 2 & 378.604 & 5.337 & $.007^{\mathrm{b}}$ \\
\hline & Residual & 4610.851 & 65 & 70.936 & & \\
\hline & Total & 5368.059 & 67 & & & \\
\hline \multicolumn{7}{|c|}{ a. Dependent Variable: Efektivitas SIKD } \\
\hline
\end{tabular}

Sumber : Output SPSS 
Dari hasil uji F diperoleh bahwa Fhitung $(5.337)>$ Ftabel $(3,14)$ dengan taraf signifikansi 0,007 <0,05, maka Ho ditolak dan Ha diterima, berarti sistem pengendalian internal pemerintah dan ketersediaan anggaran secara simultan berpengaruh terhadap efektivitas penerapan sistem informasi keuangan daerah.

\section{g. Koefisien Determinasi}

Tabel 10

Koefisien Determinasi

\begin{tabular}{|l|r|r|r|r|r|}
\hline \multicolumn{7}{|c|}{ Model Summary $^{\mathbf{b}}$} \\
\hline Model & $\mathrm{R}$ & R Square & $\begin{array}{c}\text { Adjusted R } \\
\text { Square }\end{array}$ & $\begin{array}{c}\text { Std. Error of the } \\
\text { Estimate }\end{array}$ & Durbin-Watson \\
\hline 1 & $.376^{\mathrm{a}}$ & .141 & .115 & 8.42236 & 2.113 \\
\hline \multicolumn{7}{|l}{ a. Predictors: (Constant), Ketersediaan Anggaran, SPIP } \\
\hline
\end{tabular}

Source : Output SPSS

Dari hasil pengolahahan data di dapatkan bahwa efektivitas penerapan sistem informasi keuangan daerah mampu dijelaskan oleh variabel sistem pengendalian internal pemerintah dan ketersediaan anggaran sebesar 0,115 (11,5\%), sedangkan selebihnya $88,5 \%$ dijelaskan oleh sebab-sebab lain yang tidak diketahui dalam penelitian ini.

\subsection{Pembahasan}

\section{a. Pengaruh Sistem Pengendalian Intern Pemerintah Terhadap Efektivitas Penerapan Sistem Informasi Keuangan Daerah.}

Hasil penelitian yang diperoleh dari hasil pengujian hipotesis mengenai pengaruh sistem pengendalian intern pemerintah terhadap efektifitas penerapan sistem informasi keuangan daerah menunjukkan bahwa nilai thitung sistem pengendalian internal pemerintah sebesar 1,307 dan $t_{\text {tabel }}$ sebesar 1,996 dengan $\alpha=5 \%$. Dengan demikian $t_{\text {tabel }}$ lebih besar dari thitung, dan nilai signifikansi sebesar 0,196 (lebih besar dari 0,05) artinya $\mathrm{H}_{0}$ diterima dan $\mathrm{H}_{\mathrm{a}}$ ditolak. Hal ini menunjukkan bahwa sistem pengendalian intern pemerintah tidak berpengaruh terhadap efektivitas penerapan sistem informasi keuangan daerah. Beberapa hal yang diduga menjadi faktor bahwa sistem pengendalian intern pemerintah tidak berpengaruh terhadap efektivitas penerapan sistem informasi keuangan daerah adalah bahwa sebahagian besar Pemerintah Daerah di Sumatera Utara telah menggunakan SIMDA sebagai aplikasi sistem informasi keuangan daerah. 
Program aplikasi SIMDA adalah suatu program aplikasi yang ditujukan untuk membantu pemerintah daerah dalam pengelolaan keuangan daerahnya. Dengan aplikasi ini, pemda dapat melaksanakan pengelolaan keuangan daerah secara terintegrasi, dimulai dari penganggaran, penatausahaan hingga akuntansi dan pelaporannya (BPKP, 2008). Lebih lanjut (BPKP, 2008) menjelaskan bahwa SIMDA telah didukung dengan pengendalian internal yang memadai untuk memastikan efektivitas dan efisiensi penerapan sistem yang dirancang melalui beberapa jenis pengendalian yaitu meliputi pengendalian akses dan wewenang user, pengendalian keamanan umum, pengendalian menu berdasarkan fungsi dan pengendalian aplikasi. Hal ini menunjukkan bahwa SIMDA telah dibangun dengan sistem pengendalian internal yang baik, sehingga sistem pengendalian intern pemerintah yang dibangun oleh Pemerintah Daerah tidak begitu mempengaruhi efektivitas penerapan sistem informasi keuangan daerah.

Hasil pada penelitian ini tidak mendukung sepenuhnya penelitian yang dilakukan oleh (Kurniawan, 2017; Sari, 2015; Sudirman, 2016) yang menyatakan bahwa sistem pengendalian intern berpengaruh terhadap sistem informasi akuntansi. Oleh karena itu berdasarkan penelitian di atas, maka dapat diambil kesimpulan bahwa dengan dibangunnya SIMDA oleh BPKP yang sudah membangun sistem yang dilengkapi dengan pengendalian internal yang baik, maka pengendalian internal yang dilakukan oleh Pemerintah Daerah bersifat untuk melengkapi dan melakukan koordinasi dengan BPKP selaku tim yang membangun aplikasi tersebut agar penerapan sistem tersebut tetap dapat berjalan dengan efektif.

\section{b. Pengaruh Ketersediaan Anggaran Terhadap Efektivitas Penerapan Sistem Informasi Keuangan Daerah.}

Hasil penelitian yang diperoleh dari hasil pengujian hipotesis mengenai pengaruh ketersediaan anggaran terhadap efektifitas penerapan sistem informasi keuangan daerah

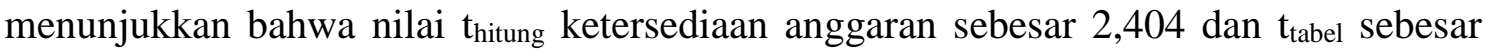
1,965 dengan $\alpha=5 \%$. Dengan demikian $t_{\text {tabel }}$ lebih besar dari $t_{\text {hitung, }}$ dan nilai signifikansi ebesar 0,019 (lebih kecil dari 0,05) artinya $\mathrm{H}_{0}$ ditolak dan $\mathrm{H}_{\mathrm{a}}$ diterima. Hal ini menunjukkan bahwa ketersediaan anggaran berpengaruh terhadap efektivitas penerapan sistem informasi keuangan daerah. Dari keseluruhan Pemerintah Daerah yang ada di Sumatera Utara, sebanyak 30 daerah menggunakan aplikasi SIMDA dari BPKP dan 
sebanyak 4 daerah membangun sistem informasi keuangannya sendiri. Untuk tetap mendukung agar sistem informasi keuangan dimaksud dapat diterapkan dengan efektif, maka seharusnya daerah menyediakan anggaran yang akan menunjang kelancaran operasional sistem tersebut.

Dimensi sumber anggaran adalah merupakan hal yang sangat penting untuk mendukung efektivitas penerapan sistem informasi keuangan daerah. Hal ini dapat terlihat dari tanggapan responden yang menyatakan bahwa ketersediaan sumber anggaran baik yang berasal dari APBN maupun dari APBD sangat dibutuhkan untuk mendukung agar sistem dapat tetap berjalan dengan efektif. Ketersediaan anggaran sangat dibutuhkan baik oleh Pemerintah Daerah yang membangun sistem informasi keuangannnya sendiri maupun Pemerintah Daerah yang menggunakan SIMDA sebagai sistem informasi keuangannya. Ketersediaan anggaran ini sangat dibutuhkan untuk menunjang operasional pelaksanaan sistem dimaksud, seperti pengadaan perangkat hardware, pelatihan sumber daya manusia, biaya perawatan, biaya jaringan internet dan yang lainnya.

Penelitian ini sejalan dengan penelitian (Riawan, 2016) yang menyatakan bahwa proses perencanaan pembangunan daerah perlu diimbangi dengan ketersediaan beberapa hal seperti: kualitas aparatur pemerintah, sumber daya baik sumber daya manusia maupun sumber dana. ketersediaan anggaran mempengaruhi efektivitas penerapan sistem informasi keuangan daerah, penelitian yang dilakukan oleh (Idris, 2013) yang menyatakan bahwa terdapat pengaruh antara ketersediaan anggaran dengan kinerja aparatur Selanjutnya (Sudaryanti, 2013) dalam penelitiannya menyatakan bahwa penganggaran berpengaruh secara signifikan terhadap kinerja melalui SIKD. SIKD merupakan sarana untuk membantu penyusunan anggaran, selanjutnya anggaran yang disusun memuat indikator kinerja sebagai tolok ukur keberhasilan pelaksanaan anggaran.

Struktur APBD Pemerintah daerah saat ini sebahagian besar anggaran masih dialokasikan untuk kebutuhan belanja pegawai. Sehingga pemerintah daerah sangat membutuhkan alokasi dana yang tersedia untuk menunjang kebutuhan sistem informasi keuangan daerah yang meliputi pembangunan, perawatan dan pemeliharaan sistem informasi keuangan termasuk hardware, software dan brainware sistem dimaksud, sehingga ketersediaan anggaran dapat mendukung efektivitas sistem informasi keuangan daerah yang akan diterapkan. 


\section{c. Pengaruh Sistem Pengendalian Intern Pemerintah dan Ketersediaan Anggaran Terhadap Efektivitas Penerapan Sistem Informasi Keuangan Daerah.}

Hasil pengujian hubungan secara simultan antara variabel eksogen (sistem pengendalian intern pemerintah dan ketersediaan anggaran) terhadap variabel endogen (efektivitas penerapan sistem informasi keuangan daerah) di peroleh nilai $F_{\text {hitung }}$ adalah sebesar 5.337 dan $F_{\text {tabel }}$ sebesar 3,14 dengan $\alpha=5 \%$. Dengan demikian $F_{h i t u n g}$ lebih besar dari $\mathrm{F}_{\text {tabel, }}$ dan nilai signifikansi sebesar 0,007 (lebih kecil dari 0,05) artinya $\mathrm{H}_{0}$ ditolak dan $\mathrm{H}_{\mathrm{a}}$ diterima. Hal ini menunjukkan bahwa secara simultan variabel eksogen (sistem pengendalian intern pemerintah dan ketersediaan anggaran) berpengaruh terhadap variabel endogen (efektivitas penerapan sistem informasi keuangan daerah).

Dengan nilai koefisien determinasi $\mathrm{R}^{2}$ yaitu sebesar 0.141 maka hal ini menunjukkan bahwa seluruh variabel bebas yang meliputi sistem pengendalian intern pemerintah, ketersediaan anggaran dapat menjelaskan variasi naik turunnya efektivitas penerapan sistem informasi keuangan daerah sebesar $14.1 \%$ sedangkan sisanya sebesar $85.9 \%$ dijelaskan oleh faktor lain yang tidak terdapat dalam penelitian ini. Berikutnya nilai koefisien determinasi yang disesuaikan (Adjusted $R^{2}$ ) sebesar 0.115 menunjukkan bahwa setelah mempertimbangkan derajat kebebasan (degree of freedom) seluruh variabel bebas yang digunakan hanya mampu menjelaskan variasi yang terjadi dalam penerapan sistem informasi keuangan daerah sebesar $11.5 \%$.

Beberapa faktor yang diduga menjadi faktor lain yang berpengaruh terhadap efektivitas penerapan sistem informasi keuangan daerah. Menurut penelitian (Sari, 2015), faktor lain yang mempengaruhi kesuksesan penerapan sistem informasi akuntansi pada pemerintah daerah antara lain adalah budaya organisasi, kompetensi dan komitmen organisasional.

\section{KESIMPULAN, IMPLIKASI DAN KETERBATASAN PENELITIAN}

Berdasarkan hasil penelitian, maka dapat diambil kesimpulan dari ini yaitu sebagai berikut :

1. Sistem pengendalian intern pemerintah tidak berpengaruh terhadap efektivitas penerapan sistem informasi keuangan daerah. Hal ini berarti dengan penggunaan aplikasi SIMDA yang dikembangkan oleh BPKP sebagai sistem informasi keuangan 
daerah, maka pengendalian intern yang dilakukan oleh pemerintah daerah tidak berpengaruh terhadap efektivitas penerapan sistem informasi keuangan daerah.

2. Ketersediaan anggaran berpengaruh signifikan terhadap efektivitas penerapan sistem informasi keuangan daerah. Hal ini berarti agar pemerintah daerah dapat menerapkan sistem informasi keuangan daerah dengan efektif, maka pemerintah daerah harus mengalokasikan anggaran yang mendukung untuk operasional pelaksanaan sistem informasi dimaksud.

3. Sistem pengendalian internal dan ketersediaan anggaran secara simultan berpengaruh terhadap efektivitas penerapan sistem informasi keuangan daerah.

Dari hasil penelitian ini, penulis juga mengemukakan beberapa saran antara lain sebagai berikut :

1. Dari segi ketersediaan anggaran, diharapkan agar pemerintah daerah tetap mengalokasikan anggaran untuk menunjang kebutuhan yang berkaitan dengan operasional pelaksanaan sistem informasi keuangan daerah yang meliputi pengadaan sarana dan prasarana, biaya pelatihan untuk pengguna, biaya sosialisasi dan biaya pengendalian/monitoring untuk mengatasi risiko yang mungkin atas penerapan sistem informasi dimaksud.

2. Efektivitas penerapan sistem informasi keuangan daerah adalah merupakan suatu instrumen (tools) yang digunakan untuk menghasilkan laporan keuangan yang berkualitas. Oleh karena itu bagi Pemerintah Daerah baik yang menggunakan SIMDA yang dikembangkan oleh BPKP sebagai sistem informasi keuangannya maupun yang membangun sistem informasi keuangannya sendiri harus tetap memastikan agar penerapan sistem tersebut berjalan dengan efektif dengan memperhatikan seluruh aspek yang meliputi kualitas sistem, kualitas informasi, penggunaan sistem, dampak individual dan dampak organisasi berjalan dengan baik, yaitu dengan cara melengkapi sistem informasi keuangan dengan program yang terintegrasi dari mulai perencanaan, penatausahaan sampai kepada pelaporan. Pengembangan aplikasi secara dinamis dan fleksibel adalah hal yang harus menjadi perhatian bagi pemerintah daerah, Adanya sinkronisasi pencatatan antara sistem informasi barang dan sistem informasi keuangan dapat membantu untuk mengintegrasikan laporan barang dan keuangan sehingga lebih memudahkan untuk 
menghasilkan neraca sebagai salah satu unsur dalam laporan keuangan yang pada akhirnya dapat menyajikan laporan keuangan yang berkualitas.

3. Penelitian ini menganalisis pengaruh sistem pengendalian intern pemerintah dan ketersediaan anggaran terhadap efektivitas penerapan sistem informasi keuangan daerah. Sehingga diharapkan penelitian ini dapat dikembangkan dengan menambah variabel lain yang mempengaruhi efektivitas sistem informasi keuangan daerah dan kualitas laporan keuangan, seperti gaya kepemimpinan, budaya organisasi, komitmen pimpinan, pemanfaatan teknologi informasi dan lain sebagainya sehingga dapat memberikan temuan yang lebih bervariasi untuk melengkapi hasil penelitian ini.

\section{DAFTAR PUSTAKA}

Alvin A. Arens, Randal J. Elder, M. S. B. (2010). Auditing and Assurance Services: An Integrated Approach. Prentice Hall.

Anthony, N. Robert dan Govindarajan, V. (2011). Sistem Pengendalian Manajemen (Jilid 2). Tangerang: Karisma Publishing Group.

Arfianti, D. (2011). Faktor-faktor yang Mempengaruhi Nilai Informasi Pelaporan Keuangan Pemerintah Daerah DAERAH ( Studi pada Satuan Kerja Perangkat Daerah di Kabupaten Batang ). Skripsi.

Ayuni, N. M. K., \& Erawati, N. M. A. (2018). Pengaruh Asimetri Informasi Pada Senjangan Anggaran Dengan Kejelasan Sasaran Anggaran dan Komitmen Organisasi Sebagai Pemoderasi. E-Jurnal Akuntansi Universitas Udayana, 22(1), 492-520. https://doi.org/https://doi.org/10.24843/EJA.2018.v22.i01.p19

Bae, B., Epps, R. W., \& Gwathmey, S. S. (2003). Internal Control Issues: The Case of Changes to Information Processes. Information Systems Control Journal, 4(804).

BPKP, S. P. S. (2008). SIMDA dan Penerapannya. Jakarta: Satgas Pengembangan SIMDA 2008. SIMDA dan Penerapannya. Jakarta: Badan Pemeriksa Keuangan dan Pembangunan.

DeLone, W. H. dan E. R. M. L. (1992). Information System Success : The Quest for the Dependent Variable.

Edition, T., \& Traver, C. G. (2012). Management information system laudon 12th edition pdf Management information system laudon 12th edition pdf.

Efendi, L., Darwanis, \& Abdullah, S. (2017). Faktor-Faktor Yang Mempengaruhi Kualitas ( Studi pada Satuan Kerja Perangkat Kabupaten Aceh Tengah ). Jurnal Perspektif Ekonomi Darussalam, 3(September), 182-195.

Elvira Zeyn. (2012). Pengaruh Penerapan Good Governance Dan Standar Akuntansi Pemerintahan Terhadap Kualitas Informasi Keuangan. Jurnal Ilmiah, 1(1), 1-14.

Farhoomand, A. F. (1998). A Hierarchical Structural Model Of Information Systems 
Success AU - Drury, D.H. INFOR: Information Systems and Operational Research, 36(1-2), 25-40. https://doi.org/10.1080/03155986.1998.11732341

Hall, J. A. (2004). Accounting Information Systems 9E. South Western: Thomson.

Huda, P. A., Ekawati, R. K., \& Pratiwi, R. (2017). Pengaruh Penerapan Sistem Informasi Akuntansi terhadap Pengendalian Internal ( Studi Empiris Pada Perusahaan BUMN di Kota Palembang ), (x), 1-14.

Idris, A. (2013). Pengaruh ketersediaan anggaran dan jiwa kewirausahaan terhadap kinerja pelayanan aparatur skpd di kabupaten aceh utara. Jurnal Kebangsaan, 2(4), 28-36.

Iman Bastari (Anggota Komite Kerja Standar Akuntansi Pemerintahan. (2004). Penerapan Sistem Akuntansi Keuangan Daerah dan Standar Akuntansi Pemerintahan sebagai wujud reformasi manajemen keuangan daerah, 1-22.

Indonesia, P. R. (2005). Peraturan Pemerintah Nomor 56 Tahun 2005 tentang Sistem Informasi Keuangan Daerah.

Indonesia, P. R. (2008). Peraturan Pemerintah Nomor 60 Tahun 2008 tentang Sistem Pengendalian Intern Pemerintah, 282.

Ir. H. Dede Hermasah, M. S. (2008). Tanpa Dukungan Ketersediaan Anggaran Rencana Pembangunan Tak Akan Bisa Diwujudkan.

Ismail, N. A. (2009). Factors Influencing AIS Effectiveness Among Manufacturing SMEs: Evidence From Malaysia. The Electronic Journal of Information Systems in Developing Countries, 38(1), 1-19. https://doi.org/10.1002/j.16814835.2009.tb00273.x

Kaho, J. R. (2010). Prospek Otonomi Daerah di Negara Republik Indonesia. Yogyakarta: PT. RajaGrafindo Persada.

Kementerian Keuangan RI. (2018). Akuntansi dan Pelaporan Keuangan Pemerintah Indonesia Dari Masa ke Masa.

Kurniawan, A. (2017). Pengaruh Pengendalian Internal Terhadap Kualitas Sistem Informasi Akuntansi Dan Dampaknya Terhadap Kualitas Informasi Akuntansi, $X I V(2), 1-12$.

Mahmudi. (2010). Manajemen Keuangan Daerah. Jakarta: Erlangga.

Mardiasmo. (n.d.). Akuntansi Sektor Publik. Yogyakarta: Penerbit Andi.

Mardiasmo. (2006). Perwujudan Transparansi dan Akuntabilitas Publik Melalui Akuntansi Sektor Publik: Suatu Sarana Good Governance. Jurnal Akuntansi Pemerintah, 2, 1-17.

Mardiasmo. (2009). Akuntansi Sektor Publik. Yogyakarta: Penerbit Andi.

Mulyadi. (2008). Sistem Akuntansi. Jakarta: Salemba Empat.

Nurhayati, I. F. I. D. (2013). Pengaruh Anggaran dan Pengendalian Terhadap Efektivitas Kinerja Satuan Kerja Perangkat Daerah (SKPD) Di Kabupaten Malang. Jurnal Manajemen Dan Akuntansi, 2(April), 95-107.

Ratifah, I., \& Ridwan, M. (2012). Komitmen Organisasi Memoderasi Pengaruh Sistem Akuntansi Keuangan Daerah terhadap Kualitas Laporan Keuangan. Trikonomika, 11(1), 29-39. 
Riawan. (2016). Pengaruh Kualitas Sumber Daya Manusia dan Kualitas Anggaran Terhadap Kinerja Keuangan Daerah Yang Dimoderasi Dengan SIMDA Pada SKPD Kabupaten Buton Utara. JESP-Vol. 8, No 1 Maret 2016 ISSN (P) 20861575 E-ISSN 2502-7115, 8(1), 50-60.

Rusvianto, D., Mulyani, S., \& Yuliafitri, I. (n.d.). Pengaruh Pelaksanaan Sistem Pengendalian Internal Pemerintah dan Kompetensi Sumber Daya Manusia Terhadap Kualitas Laporan Keuangan Pemerintah Daerah (Studi Empiris pada SKPD Kota Bandung), 33-67.

Sari, E. N. (2015). The Influence of Governmet Internal Control System, Organizational Culture, Competency And Organizational Comitment On The Accounting Information System Implementation's Success And It's Implication On The Financial Statements Quality. Universitas Padjajaran.

Simanjuntak, B. H. (2012). SPIP Mampu Tingkatkan Akuntabilitas Keuangan Pemda. Retrieved from www.bpkp.go.id

Suarmika, I. G. L., \& Suputra, I. D. G. D. (2016). Kemampuan Komitmen Organisasi dan Sistem Pengendalian Intern Memoderasi Pengaruh Kapasitas Sumber Daya Manusia dan Penerapan SIKD Pada Kualitas LKPD Kabupaten KarangAsem. EJurnal Ekonomi Dan Bisnis, 5.9, 2921-2950.

Sudaryanti, D. (2013). Pengaruh Penganggaran Terhadap Kinerja Aparat Pemda Melalui Sistem Informasi Keuangan Daerah (Studi Kasus : Pemda Kab. Kudus), 12, 1124.

Sudirman, M. S. (2016). Pengaruh Pengendalian Intern Terhadap Sistem Informasi Akuntansi Penerimaan Kas (BMA Executive Travel Makassar).

Sugiyono. (2010). Metode Penelitian Kuantitatif, Kualitatif dan $R \&$ D. Bandung: Alfabeta.

Supriyono. (1987). Akuntansi Biaya : Pengumpulan Biaya dan Penentuan Harga Pokok Produk (Edisi Kedu). Yogyakarta: BPFE Universitas Gajah Mada.

Susanto, A. (2008). Sistem Informasi Akuntansi: Struktur Pengendalian Resiko Pengembangan (Cetakan Pe). Bandung: Lingga Jaya.

Syarifudin, A. (2014). Pengaruh Kompetensi SDM dan Peran Audit Intern terhadap Kualitas Laporan Keuangan Pemerintah Daerah dengan Variabel Intervening Sistem Pengendalian Internal Pemerintah (studi empiris pada Pemkab Kebumen). Fokus Bisnis, 14(25), 26-44. https://doi.org/10.1080/10587250210796

William H. DeLone and Ephraime R. McLean. (2003). The DeLone and McLean Model of Information System Success. Journal of Management Information Systems, 19(4), 9-30. https://doi.org/10.1080/07421222.2003.11045748. 